\title{
Grants and opportunities
}

\section{Call for applications for Cambridge Masters in Conservation Leadership, October 2016}

The Cambridge Masters in Conservation Leadership is a full-time, 11-month course, aimed at graduates with leadership potential who have at least 3-5 years of relevant experience in conservation. The unique features of this course are its delivery by a partnership between university departments and conservation organizations, and its focus on issues of management and leadership. The goal is not only to develop conservationists with enhanced research skills and greater awareness of the complex drivers of biodiversity loss but also to develop their ability to act and lead effectively. This includes the development of professional management and leadership skills, including strategic planning, finance, HR management, innovation, entrepreneurship and the management of change. The course fosters the leadership potential of its students by promoting their capacity to understand the links amongst the drivers of biodiversity loss, and to think creatively about conservation solutions across organizational and political boundaries and economic sectors.

This Masters has its academic base in the Department of Geography at the University of Cambridge, which collaborates with partners in the Cambridge Conservation Initiative to deliver the course. By October 2016, Masters students will be co-located in the new Conservation Campus alongside c. 500 conservationists from the Cambridge Conservation Initiative.

Application for entry to the course in October 2016 opens in September 2015. Several full or partial scholarships are available for applicants from less developed and developing countries. Further funds are available from the Cambridge Trusts. To be eligible for all scholarships applicants must apply by early December 2015. Full details of the course, how to apply, and funding opportunities can be found at http://www.geog.cam.ac.uk/graduate/mphil/conservation

\section{Call for Applications for 2016 Conservation Leadership Programme Conservation Awards}

The Conservation Leadership Programme (CLP) is a training and capacity-building programme that targets earlycareer conservationists from developing countries who demonstrate leadership potential. This partnership of BirdLife International, Fauna \& Flora International and the Wildlife Conservation Society has been supporting young conservationists for 30 years by awarding project funding, training, networking and mentoring support.

In 2016 CLP will be granting Future Conservationist Awards (up to USD 12,500 each) for new applicants and
Conservation Follow-up Awards (up to USD 20,000 each) for previous CLP Future Conservationist Award winners. CLP will also offer one Conservation Leadership Award (up to USD 40,000) to a previous CLP Follow-up Award winner.

The application deadline for 2016 awards will be in November 2015 and application materials will be available on the CLP website in August. Awards will be announced in April 2016. Applicants are encouraged to contact a CLP staff member for advice well before the application deadline. Staff members can help teams determine if their project fits the specified criteria, offer advice on methods and project activities, and put teams in touch with local partner offices or other experts who can provide additional advice.

Eligibility criteria, award guidelines and the application form are available at http://www.conservationleadership programme.org; e-mail clp@birdlife.org

\section{Call for applications for the Whitley Awards 2016}

The Whitley Fund for Nature is a UK registered charity offering Whitley Awards to outstanding nature conservation leaders in the developing world. The Awards aim to identify, recognize and fund the most dynamic, inspirational and effective conservation leaders and their teams working in middle- and low-income countries; to focus on local leaders who are nationals of the countries or regions where they are working; to support work that is rooted in good science or research but that also emphasizes the benefits of biodiversity and ecosystems to local communities; to fund pragmatic projects that aim to have a measurable, long-lasting impact; and to raise the profile of winners and help them network effectively, educate others and heighten public awareness of the problems facing biodiversity and ecosystems worldwide.

Whitley Awards are the result of a competitive process and are presented at the annual Whitley Awards Ceremony in London each spring. Winners join a growing network of over 170 winners across 70 countries. Whitley Fund for Nature stays in close contact with winners and the most successful can apply for additional Continuation Funding of up to GBP 70,000 .

The deadline for applications for the next Whitley Awards is 31 October 2015. Potential applicants can read about the eligibility requirements at http://www.whi tleyaward.org. The 2016 application form and detailed guidance notes will be available from July 2015. Please note that Whitley does not fund undergraduate projects, expeditions, Master's research, or pure-research PhD work. If you have any questions regarding the Whitley Awards, please e-mail Danni Parks at danni@whitleyaward.org 